\title{
Non-Toxic Effect of Monascus purpureus Extract on Lactic Acid Bacteria Suggested Their Application in Fermented Foods
}

\author{
Mohan-Kumari Honganoor Puttananjaiah ${ }^{1}$, Mohan Appasaheb Dhale ${ }^{2}$, Vijayalakshmi Govindaswamy ${ }^{1}$ \\ ${ }^{1}$ Department of Food Microbiology, Central Food Technological Research Institute, Council of Scientific and Industrial Research, \\ Mysore, India; ${ }^{2}$ Biological Oceanography Division, National Institute of Oceanography, Council of Scientific and Industrial Re- \\ search, Dona Paula, India. \\ Email: \{vij19_99, dhalemohan\}@yahoo.com
}

Received May $9^{\text {th }}, 2011$; revised August $2^{\text {nd }}, 2011$; accepted August $9^{\text {th }}, 2011$.

\begin{abstract}
The effect of Monascus purpureus extract (MPE) on probiotic lactic acid bacteria (LAB) was investigated to ascertain its application in fermented foods. Viable count of LAB was not affected after 24 hours of incubation in Man Rogosa Sharpe (MRS) broth containing MPE. The agar well-diffusion assay did not show any inhibition zone. The biotransformation of isoflavone glycosides by LAB in culture medium supplemented with MPE increased antioxidant activities. These data suggest that, nutritive and biological functionality of fermented foods can be improved by the use of MPE.
\end{abstract}

Keywords: M. purpureus, Fermented Foods, Lactobacillus, Antioxidant

\section{Introduction}

Monascus sp. have been used commercially to produce valuable secondary metabolites viz., pigments [1,2], monacolin K (lovastatin), hypotensive agent, $\gamma$-aminobutyric acid, 3-hydoxy-4-methoxy-benzoic acid [3,4]. Feeding of M. purpureus red mould rice demonstrated significant decrease TC, TG, and LDL-C levels in hyperlipidemic hamsters. Monacolin K (lovastatin) is a potent competitive inhibitor of 3-hydroxy-3-methylglutaryl coenzyme A (HMG-CoA) reductase enzyme [5]. Dimerumic acid, dihydromonacolin-MV and dehydromonacolin-MV2 isolated from Monascus sp. have been characterized for their antioxidant action [6-8]. Our earlier study on toxicity of RMR did not show any adverse effect on rats and significantly reduced the cholesterol and triacylglycerol levels in serum and liver [9]. Orange pigments (monascorubrin and rubropunctatin) inhibited the growth of $B a-$ cillus subtilis, Escherichia coli, some filamentous fungi and yeasts [10]. Amino acid derivatives of Monascus pigments L-Phe, D-Phe, L-Tyr, and D-Tyr exhibited high activities against Gram + ve and Gram -ve bacteria. Derivatives with L-Asp, D-Asp, L-Tyr and D-Tyr were effective against the filamentous fungi Aspergillus niger, Penicillium citrinum and Candida albicans [11]. The use of Monascus cultures as food additives is not approved either in the EU or in the USA, though it is currently permitted in Japan. It has been traditionally used for manufacturing food colorants (e.g. red rice) and fermented foods and beverages in Southern and Far Eastern Asia [3]. Monascus pigments were used as colouring agents in preparation of sausage, hams, fish paste, surimi and tomato ketchup [12]. However, there are no reports on the M. purpureus isoflavones and their bioconversion. In this study we have identified the non-toxic effect of MPE on lactic acid bacteria (LAB) and biotransformation of isoflavone glycosides by LAB in culture medium supplemented with MPE. Consequently, providing food products with aglycones would be considered as a novel trend for the food industry.

\section{Materials and Methods}

\subsection{Microorganisms and Culture Conditions}

The microorganisms M. purpureus MTCC 410, Lactobacillus acidophilus B4496 (La), L. bulgaricus CFR2028 (Lb), L. casei B1922 (Lc), L. plantarum B4495 (Lp) and L. helviticus B4526 (Lh) were obtained from Microbial Type Culture Collection (MTCC), Institute of Microbial Technology (IMTECH) Chandigarh, India. The M. purpureus and LAB cultures were maintained on PDA and MRS media (Himedia Laboratories, Mumbai, India) 
respectively at $4^{\circ} \mathrm{C}-8^{\circ} \mathrm{C}$. Seed culture was prepared according to method of Su et al., by inoculating M. purpureus spores into a $500 \mathrm{ml}$ flask containing $100 \mathrm{ml}$ basal medium and incubated for $48 \mathrm{~h}$ at $30^{\circ} \mathrm{C}$. The seed culture inoculum was used for solid state fermentation [3]. The medium $\mathrm{pH}$ was adjusted to 6.0 prior to sterilization.

Sterile, debraned and cooked rice was inoculated with $5 \%(\mathrm{v} / \mathrm{w})$ seed culture of M. purpureus in $500 \mathrm{ml}$ conical flasks. The inoculum was incubated at $30^{\circ} \mathrm{C}$ in a slanting position for 14 days with intermittent shaking of the flask. After incubation the fermented red rice was dried at $45^{\circ} \mathrm{C}$ $-50^{\circ} \mathrm{C}$ for $24 \mathrm{~h}$ and powdered. The powder was used to prepare MPE using methanol $(1: 4 \mathrm{w} / \mathrm{v})$. The extraction was carried on rotary shaker at $150 \mathrm{rpm}$ for $60 \mathrm{~min}$ at $70^{\circ} \mathrm{C}$. This was centrifuged at $20^{\circ} \mathrm{C}$ with $18,000 \mathrm{rpm}$ for 30 min and supernatant was collected. The supernatant was vacuum concentrated and lyophilized to completely remove methanol and water (Buchi, Flawil, Switzerland) and stored at $4{ }^{\circ} \mathrm{C}$ for further analysis. The MPE dissolved in DMSO $(5 \mathrm{mg} / \mathrm{ml})$ was used to determine viable counts and inhibitory activity.

Five strains of LAB cultures maintained in MRS agar stabs were activated after two successive transfers in MRS broth at $37^{\circ} \mathrm{C}$ for $12 \mathrm{~h}-15 \mathrm{~h}$. Again these activated cultures were inoculated into MRS broth. After incubation at $37^{\circ} \mathrm{C}$ for $16 \mathrm{~h}$, approximately $7-8 \log _{10} \mathrm{CFU} / \mathrm{ml}$ were used for experimental purpose.

\subsection{Determination of Viable Counts of LAB}

Viable cell counts of LAB were determined by pour plate method [13]. Each $1 \mathrm{ml}$ LAB suspension and MPE were added to $8 \mathrm{ml}$ of sterile $0.85 \%$ saline and incubated at $37^{\circ} \mathrm{C}$ for 24 hours. After 24 hours the cultures were serially diluted with $9 \mathrm{ml}$ saline and $1 \mathrm{ml}$ of the appropriate dilution was used for selective enumeration by pour plate technique. After $24 \mathrm{~h}$ of incubation plates containing 25 to 250 colonies were counted and recorded as CFU. The control set of experiment for each LAB was maintained without MPE. The experiment was carried out in triplicate.

\subsection{Agar Well-Diffusion Method}

In vitro antibacterial activity was determined by the agar well-diffusion method [14]. The 16 hour LAB cultures were centrifuged at $8000 \mathrm{rpm}$ for $10 \mathrm{~min}$ at $4^{\circ} \mathrm{C}$. The supernatant was discarded and bacterial cells were resuspended in saline to make a suspension of approximately 7 - $8 \log _{10} \mathrm{CFU} / \mathrm{ml}$. Plating was carried out by transferring the bacterial suspension $(120 \mu \mathrm{l})$ to a $20 \mathrm{ml}$ sterile soft MRS agar medium and allowed to solidify. About 30, 40 and $50 \mu \mathrm{l}$ of MPE $(5 \mathrm{mg} / \mathrm{ml})$ was placed in the wells and allowed to diffuse for $1 \mathrm{~h}$ at room temperature. Plates were incubated at $37^{\circ} \mathrm{C}$ for $24 \mathrm{~h}$ to determine inhibition zones. The assay was carried out in triplicate.

\subsection{Analysis of Isoflavones}

Isoflavones were analysed according to the method of Chiou and Cheng [15]. The stock solutions were prepared by dissolving daidzin, genistin, daidzein and genistein in $80 \%$ aqueous methanol $(1 \mathrm{mg} / 10 \mathrm{ml}, \mathrm{w} / \mathrm{v})$. Each isoflavone standard solution was injected into the HPLC and the peak areas were determined. One $\mathrm{ml}$ of appropriately diluted MPE sample was filtered $(0.45 \mu \mathrm{m})$ and 20 $\mu \mathrm{l}$ of sample was injected into the HPLC system (Shimadzu, LC 10A, Japan). A reversed-phase water $\mathrm{C}_{18} \mathrm{Co}$ lumn (Spherisorb ODS 2, $4.6 \times 250 \mathrm{~mm}$ ) was used. A gradient solvent system started with $20 \%$ solvent A (methanol) and $80 \%$ solvent $\mathrm{B}$ (water) and progressed to $80 \%$ of A and $20 \%$ of B within 16 min followed by holding for an additional 2 min was followed with a flow rate of $1 \mathrm{ml} / \mathrm{min}$. The UV detection was carried out at $265 \mathrm{~nm}$ using Shimadzu diode array detector. The isoflavones in MPE were identified using standards injected under similar conditions. The concentrations of isoflavones, in 24 hours LAB culture broth supplemented with and without MPE were estimated as above.

\subsection{DPPH Radical Scavenging Assay}

The DPPH radical scavenging [16] activity was measured according to the method of Moon and Terao [17]. The reaction mixture was containing $1 \mathrm{ml}$ DPPH $(500 \mu \mathrm{M}$ in ethanol), $0.9 \mathrm{ml}$ Tris- $\mathrm{HCl}$ buffer $(100 \mathrm{mM}, \mathrm{pH} 7.4)$ and $0.1 \mathrm{ml} \mathrm{LAB}$ culture supernatant. The reaction mixture was shaken vigorously and incubated at room temperature for $30 \mathrm{~min}$. The absorbance of the resulting solution was measured at $517 \mathrm{~nm}$. All the experiments were carried out by maintaining appropriate blanks and controls. Antioxidant activity was calculated using following formula.

$$
\operatorname{Antioxidant} \operatorname{activity}(\%)=\left(1-\frac{A_{\text {sample }(517 \mathrm{~nm})}}{A_{\text {control }(517 \mathrm{~nm})}}\right) \times 100
$$

\subsection{Inhibition of Ascorbate Autoxidation}

The inhibition of ascorbate autoxidation was estimated according to the method of Kovachich and Mishra [18]. The reaction mixture containing $0.1 \mathrm{ml}$ LAB culture supernatant, $0.1 \mathrm{ml}$ ascorbate solution $(5.0 \mathrm{mM}$, Sigma Chemicals, USA) and $9.8 \mathrm{ml}$ phosphate buffer $(0.2 \mathrm{M}$, $\mathrm{pH} 7.0$ ). The reaction mixture was incubated at $37^{\circ} \mathrm{C}$ for $10 \mathrm{~min}$ and the absorbance of this mixture was read at $265 \mathrm{~nm}$. All the tests were carried out by maintaining appropriate blanks and controls. Inhibition of ascorbate autoxidation activity was calculated as follows. 


$$
\operatorname{Inhibition}(\%)=\left(\frac{A_{\text {sample }}}{A_{\text {control }}}-1\right) \times 100
$$

\subsection{Determination of Reducing Activity}

The reducing power was determined according to the method of Oyaizu [19]. Briefly, the reaction mixture was containing $0.5 \mathrm{ml} \mathrm{LAB}$ culture supernatant, $0.5 \mathrm{ml}$ sodium phosphate buffer $(200 \mathrm{mM}, \mathrm{pH} 7.0)$ and $0.5 \mathrm{ml}$ potassium ferricyanide (1\%). This mixture was incubated at $50^{\circ} \mathrm{C}$ for $20 \mathrm{~min}$ and $0.5 \mathrm{ml}$ trichloroacetic acid $(10 \%)$ was added. The mixture was centrifuged at $780 \mathrm{~g}$ for 10 $\min$. The upper layer $(1.5 \mathrm{ml})$ was mixed with $0.2 \mathrm{ml}$ of $0.1 \%$ ferric chloride and the absorbance was measured at $700 \mathrm{~nm}$ against appropriate blanks. A higher absorbance indicates a higher reducing power.

\section{Statistical Analysis}

Data was analyzed using Microsoft Excel Windows Vista (Microsoft Co., Redmond, WA, USA) and statistical analysis was performed with statistical analysis software SPSS-10 (SPSS Inc., Chicago, IL, USA). All determinations were carried out in triplicate. Statistical differences between means were determined by ANOVA and Duncan's test for multiple comparisons. P-values of $<0.05$ was considered significant.

\section{Results}

The comparative growth of the five isolates of $\mathrm{LAB}$ and its combination with MPE at $37^{\circ} \mathrm{C}$ for $24 \mathrm{~h}$ is shown in Table 1. The five LAB isolates grown in MRS broth, the highest viable count was observed in Lc $\left(9.8 \log _{10}\right.$ $\mathrm{CFU} / \mathrm{ml})$ followed by $\mathrm{Lp}\left(9.5 \log _{10} \mathrm{CFU} / \mathrm{ml}\right)$ and $\mathrm{Lh}(8.6$ $\left.\log _{10} \mathrm{CFU} / \mathrm{ml}\right)$. The isolates grown in MRS broth supplemented with MPE did not show any significant difference in their viable counts. While increase in the viable count of Lh $\left(8.8 \log _{10} \mathrm{CFU} / \mathrm{ml}\right)$ and $\mathrm{Lp}\left(9.7 \log _{10}\right.$ $\mathrm{CFU} / \mathrm{ml}$ ) was observed. The MPE did not show any inhibitory effects (agar well-diffusion assay) on LAB at different concentrations (Figure 1). These results revealed

Table 1. Cell viability of LAB grown in combination with MPE at $37^{\circ} \mathrm{C}$.

\begin{tabular}{ccc}
\hline Strian & LAB $($ CFU $)$ & MPE + LAB $(C F U)$ \\
\hline La & $7.60 \pm 0.02^{\mathrm{b}} \times 10^{9}$ & $7.59 \pm 0.12^{\mathrm{b}} \times 10^{9}$ \\
$\mathrm{Lb}$ & $5.15 \pm 0.02^{\mathrm{a}} \times 10^{9}$ & $5.16 \pm 0.13^{\mathrm{a}} \times 10^{9}$ \\
$\mathrm{Lc}$ & $9.8 \pm 0.17^{\mathrm{d}} \times 10^{9}$ & $9.78 \pm 0.12^{\mathrm{d}} \times 10^{9}$ \\
Lh & $8.6 \pm 0.46^{\mathrm{c}} \times 10^{9}$ & $8.8 \pm 0.36^{\mathrm{c}} \times 10^{9}$ \\
Lp & $9.5 \pm 0.44^{\mathrm{c}} \times 10^{9}$ & $9.7 \pm 0.11^{\mathrm{d}} \times 10^{9}$ \\
\hline
\end{tabular}

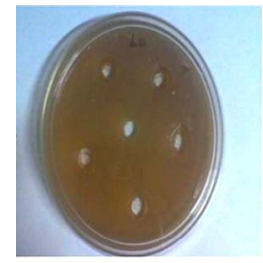

L. acidophilus

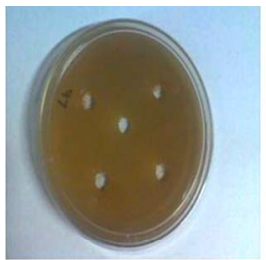

L. bulgaricus

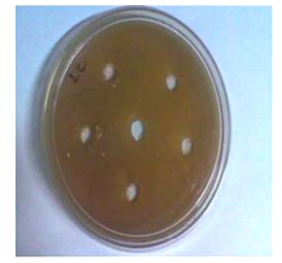

L. casei

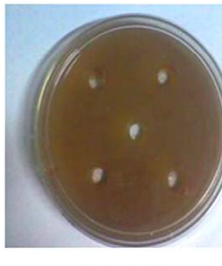

L. helviticus

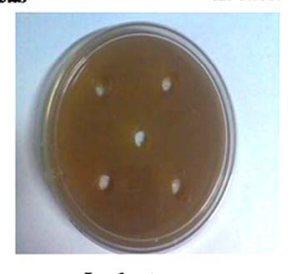

L.plantarum
Figure 1. Nontoxic effect of MPE against Lactobacillus acidophilus, L. bulgaricus, $L$. casei, L. helviticus and L. plantarum was identified by agar well-diffusion assay.

the nontoxic effect of MPE on LAB, even though it inhibited gram (+) ve and gram $(-)$ ve bacteria. This indicates that supplementation of MPE will not affect the fermentation process.

The DPPH radical scavenging activity, inhibition of ascorbate autoxidation, reducing activity of MPE and LAB were shown in Table 2. The culture filtrates of Lc, Lp and Lh have shown higher DPPH scavenging activity $(41.68 \%)$, inhibition of ascorbate (10.01\%) and reducing activity $(0.83 \mu \mathrm{M})$ respectively.

The concentration of isoflavones in MPE fermented with LAB were identified and estimated by HPLC (Figure 2).

The isoflavone isomers were eluted according to their polarity and hydrophobic interaction with the reversed phase HPLC column. Glucosidic isoflavones eluted first and then the aglycones. Within each glucosidic form of isoflavones, daidzin eluted first followed by genistin and in aglyconic form of isoflavones daidzein eluted first and then the genistein (Figure 3).

Changes occurred in the concentration of glucoside and aglycone isoflavone isomers in MPE fermented by $\mathrm{La}, \mathrm{Lb}, \mathrm{Lc}, \mathrm{Lp}$ and $\mathrm{Lh}$ for $24 \mathrm{~h}$ at $37^{\circ} \mathrm{C}$ was represented in Table 3. The MPE contained total amount glucosides $(20.39 \mathrm{mg} / 100 \mathrm{ml})$ and aglycones $(0.37 \mathrm{mg} / 100 \mathrm{ml})$. After $24 \mathrm{~h}$ of incubation, the concentration of total amo- unt aglycones in culture media of LAB was in the range of $27.98 \mathrm{mg} / 100 \mathrm{ml}-39.56 \mathrm{mg} / 100 \mathrm{ml}$ and decrease in the concentration of glucosides isoflavones were observed. The highest concentrations of aglycones were measured in the culture medium of La followed by Lh and least concentration was estimated in Lp.

\section{Discussion}

Monascus pigments are used as a food colouring agent in 
Table 2. Antioxidant activities LAB cultured in MPE.

\begin{tabular}{|c|c|c|c|}
\hline \multirow[b]{2}{*}{ Cultures } & \multicolumn{3}{|c|}{ Antioxidant activity } \\
\hline & DPPH scavenging (\%) & Inhibition of ascorbate autoxidation (\%) & $\begin{array}{c}\text { Reducing activity } \\
\text { (equivalent cysteine, } \mu \mathrm{M} \text { ) }\end{array}$ \\
\hline MPE & $35.81 \pm 0.11^{\mathrm{a}}$ & $7.31 \pm 0.24^{\mathrm{a}}$ & $0.65 \pm 0.03^{\mathrm{a}}$ \\
\hline $\mathrm{MPE}+\mathrm{La}$ & $39.08 \pm 0.13^{\mathrm{d}}$ & $9.98 \pm 0.15^{\mathrm{d}}$ & $0.70 \pm 0.04^{\mathrm{ab}}$ \\
\hline $\mathrm{MPE}+\mathrm{Lb}$ & $36.19 \pm 0.20^{\mathrm{a}}$ & $8.65 \pm 0.10^{\mathrm{c}}$ & $0.73 \pm 0.03^{\mathrm{ab}}$ \\
\hline $\mathrm{MPE}+\mathrm{Lc}$ & $41.68 \pm 0.15^{\mathrm{e}}$ & $8.18 \pm 0.17^{\mathrm{b}}$ & $0.77 \pm 0.02^{\mathrm{ab}}$ \\
\hline $\mathrm{MPE}+\mathrm{Lh}$ & $36.90 \pm 0.15^{\mathrm{b}}$ & $9.80 \pm 0.02^{\mathrm{d}}$ & $0.83 \pm 0.02^{\mathrm{b}}$ \\
\hline $\mathrm{MPE}+\mathrm{Lp}$ & $38.35 \pm 0.28^{\mathrm{c}}$ & $10.01 \pm 0.02^{\mathrm{d}}$ & $0.75 \pm 0.04^{\mathrm{ab}}$ \\
\hline
\end{tabular}

Mean values within each column with different superscripts are significantly different by Duncan's test at $P<0.05$.
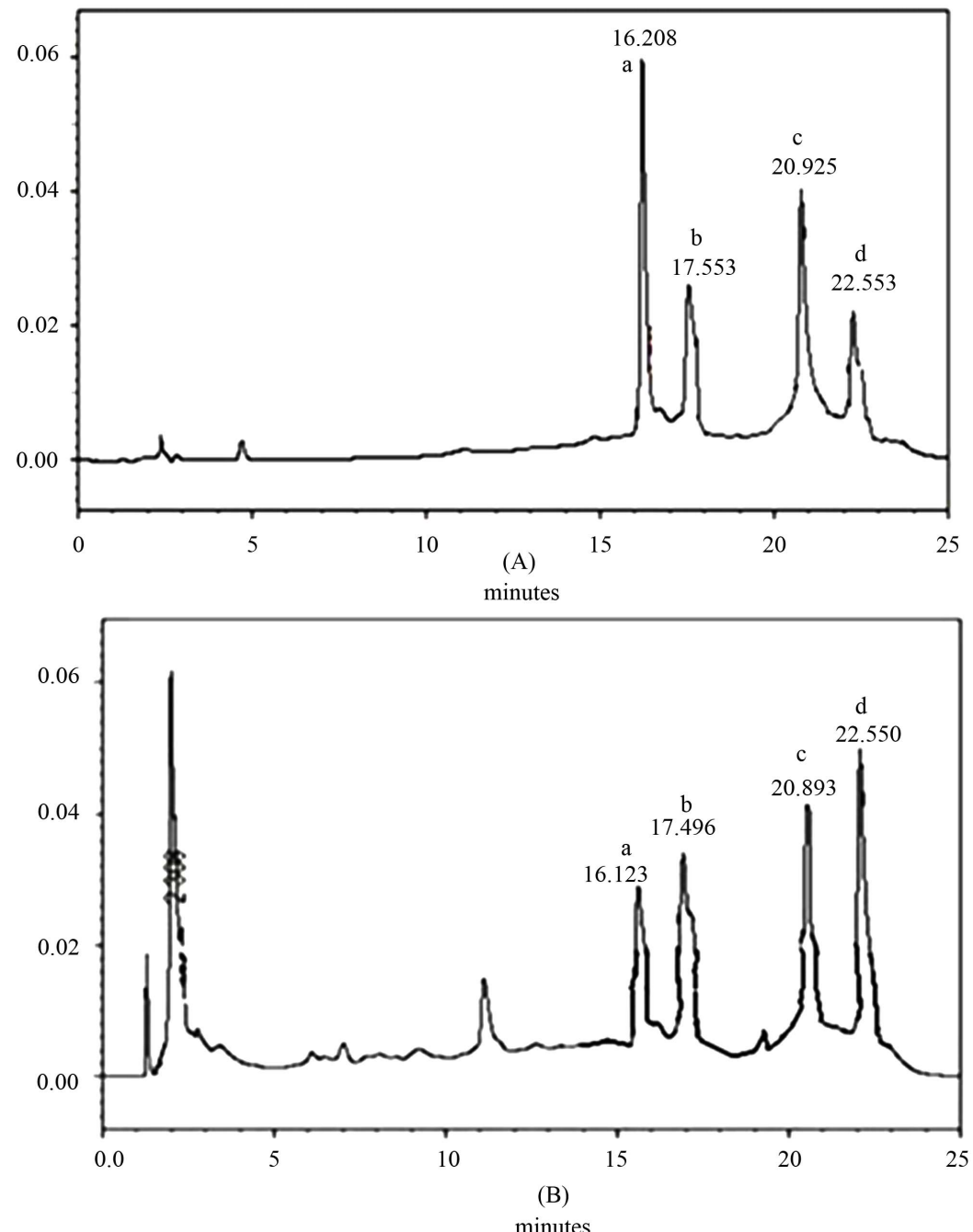

Figure 2. HPLC profile showing elution of standard isoflavones (A) daidzin (a), genistin (b), daidzein (c) and genistein (d) was used to detect the biotransformation of isoflavones by La bacteria in culture media (B) containing MPE. 


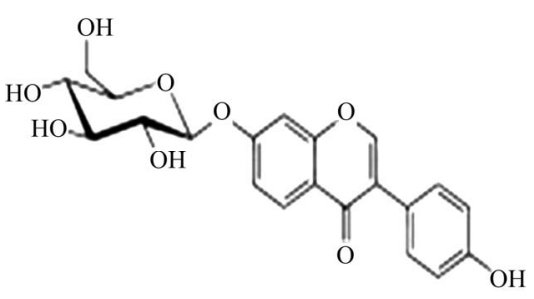

(a)

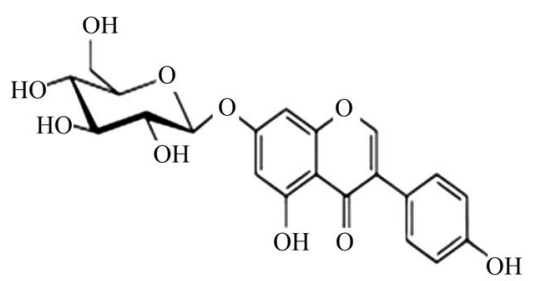

(c)<smiles>O=c1c(-c2ccc(O)cc2)coc2cc(O)ccc12</smiles>

(b)<smiles>O=c1c(-c2ccc(O)cc2)coc2cc(O)cc(O)c12</smiles>

(d)

Figure 3. The isoflavone molecules daidzin (a), daidzein (b), genistin (c) and genistein (d) were identified in MPE by HPLC using standard isoflavones.

Table 3. Isoflavone contents were estimated in LAB culture media containing MPE before and after 24 hours of incubation.

\begin{tabular}{|c|c|c|c|c|c|c|c|}
\hline \multirow{2}{*}{ Cultures } & \multicolumn{3}{|c|}{ Glucosides (mg/100 ml) } & \multicolumn{3}{|c|}{ Aglycones (mg/100 ml) } & \multirow{2}{*}{$\begin{array}{c}\text { Total } \\
(\mathrm{mg} / 100 \mathrm{ml})\end{array}$} \\
\hline & Daidzin & Genistin & Sub-total & Daidzein & Genistein & Sub-total & \\
\hline MPE & $3.38 \pm 0.04^{\mathrm{d}}$ & $17.01 \pm 0.07^{\mathrm{d}}$ & $20.39 \pm 0.11^{\mathrm{e}}$ & $0.06 \pm 0.01^{\mathrm{a}}$ & $0.31 \pm 0.03^{\mathrm{a}}$ & $0.37 \pm 0.02^{\mathrm{a}}$ & $20.76 \pm 0.12^{\mathrm{a}}$ \\
\hline $\mathrm{MPE}+\mathrm{La}$ & $0.13 \pm 0.03^{\mathrm{c}}$ & $0.79 \pm 0.01^{\mathrm{c}}$ & $0.92 \pm 0.011^{\mathrm{d}}$ & $7.89 \pm 0.03^{\mathrm{f}}$ & $30.75 \pm 0.04^{\mathrm{f}}$ & $38.64 \pm 0.02^{\mathrm{f}}$ & $39.56 \pm 0.02^{\mathrm{f}}$ \\
\hline $\mathrm{MPE}+\mathrm{Lb}$ & $0.11 \pm 0.03^{\mathrm{bc}}$ & $0.59 \pm 0.03^{\mathrm{b}}$ & $0.70 \pm 0.06^{\mathrm{c}}$ & $5.97 \pm 0.04^{\mathrm{c}}$ & $21.98 \pm 0.03^{\mathrm{c}}$ & $27.95 \pm 0.12^{\mathrm{c}}$ & $28.65 \pm 0.08^{c}$ \\
\hline $\mathrm{MPE}+\mathrm{Lc}$ & $0.05 \pm 0.03^{\mathrm{a}}$ & $0.30 \pm 0.01^{\mathrm{a}}$ & $0.35 \pm 0.04^{\mathrm{a}}$ & $4.72 \pm 0.06^{\mathrm{b}}$ & $17.16 \pm 0.03^{\mathrm{b}}$ & $21.88 \pm 0.03^{\mathrm{b}}$ & $22.23 \pm 0.01^{\mathrm{b}}$ \\
\hline $\mathrm{MPE}+\mathrm{Lh}$ & $0.07 \pm 0.02^{\mathrm{ab}}$ & $0.52 \pm 0.02^{\mathrm{b}}$ & $0.59 \pm 0.02^{\mathrm{b}}$ & $7.04 \pm 0.05 \mathrm{e}$ & $26.86 \pm 0.07^{\mathrm{e}}$ & $33.90 \pm 0.07^{\mathrm{e}}$ & $34.49 \pm 0.06^{\mathrm{e}}$ \\
\hline $\mathrm{MPE}+\mathrm{Lp}$ & $0.11 \pm 0.03^{\mathrm{bc}}$ & $0.55 \pm 0.06^{\mathrm{b}}$ & $0.66 \pm 0.03^{\mathrm{bc}}$ & $6.49 \pm 0.07 \mathrm{~d}$ & $24.17 \pm 0.11^{\mathrm{d}}$ & $30.66 \pm 0.04^{\mathrm{d}}$ & $31.32 \pm 0.07^{\mathrm{d}}$ \\
\hline
\end{tabular}

Mean values within each column with different superscripts are significantly different by Duncan's test at $P<0.05$.

a limited number of cases such as sausage, hams, fish paste, surimi and tomato ketchup. However, there are no reports on the usage of Monascus pigment in fermented foods. For preparation of fermented foods, lactic acid bacteria including Lactobacilli are the most common bacterial species considered as potential probiotics and important commensal members of the healthy human microbiota. They are useful in promotion of human health and prevention or treatment of several diseases [20]. While, antibacterial property of Monascus sp and effectiveness of monascidin-A against Bacillus, Streptococcus and Pseudomonas has been reported [21]. So, prior to increase the nutritive and nutraceutical values of fermented foods using MPE, it is necessary to evaluate the effect of MPE on LAB.

The agar well diffusion assay and viable count results revealed that, MPE do not have any bacteriostatic or bactericidal effect on LAB. Probiotic microorganisms are increasingly incorporated into food as dietary adjuncts for the purpose to benefit the human health [20] and there are several reports on applications of Monascus metabolites as a colouring [12], and antioxidant agent [6,7]. The aglycone forms of isoflavones are formed by the catalytic action of $\beta$-glucosidase [22] on glucosidic form of isoflavones during fermentation. The increase in the antioxidant capacity of $\mathrm{LAB}$ can be attributed to the biotransformation 
of glucosidic isoflavones aglycone isoflavone (genistein and daidzein). Hence, the fermented foods prepared using MPE will be more functional to reduce the oxidative stress related diseases as it contains active aglycone isoflavones. The bioconversion suggested the application of MPE along with probiotic cultures can improves the biological functionality of the fermented food products.

The MPE contains high concentration of glucoside isoflavones that are poorly bioavailable in intestine. The biological effects of $M$. purpureus isoflavones are not as a result of the glucosides but mainly from their aglycones such as daidzein and genistein. In intestine, the isoflavone aglycones are absorbed in greater amounts than their glycosides and are hydrolysed by the intestinal bacteria $[24,25]$. The variation in intestinal bacteria may occur because of illnesses, diet or age. The bioconversion and bioavailability of isoflavones depends upon the relative ability of gut microflora. Thus the intestinal bacteria cannot always be relied upon for glucoside deconjugation to release aglycones. Our results confirmed the bioconversion of biologically inactive glucosides to biologically active aglycones and nontoxic effect of MPE on LAB. The fermented foods prepared by using M. purpureus extracts may have more health beneficial effects.

\section{Acknowledgements}

Mohan-Kumari H. P. acknowledges Council of Scientific and Industrial Research, New Delhi, India and University of Mysore for supporting research through the award of Senior Research Fellowship.

\section{REFERENCES}

[1] M. A. Dhale, H. P. Mohan-Kumari, S. Umesh-Kumar and G. Vijayalakshmi, "Production of Monascus Purpureus Pigments; Influenced by Amidase and Acid Protease Activity," Journal of Food Biochemistry, Vol. 35, No. 4, 2011, pp. 1231-1241.

[2] H. C. Wong and P. E. Koehler, "Production and Isolation of an Antibiotic from Monascus Purpureus and Its Relationship to Pigment Production," Journal of Food Science, Vol. 46, 1981, No. 2, pp. 589-592. doi:10.1111/j.1365-2621.1981.tb04917.x

[3] Y. Su, J. J. Wang, T. T. Lin and T. M. Pan, "Production of the Secondary Metabolites c-Aminobutyric Acid and Monacolin K by Monascus," Journal of Industrial Microbiology and Biotechnology, Vol. 30, 2003, pp. 40-46.

[4] G. F. Wu and X. C. Wu, "Screening DPPH Radical ScavEngers from Monascus sp," Acta Microbiologica Science, Vol. 40, No. 4, 2000, pp. 394-399.

[5] C. L. Lee, T. Y. Tsai, J. J. Wang and T. M. Pan, "In Vivo Hypolipidemic Effects and Safety of Low Dosage Monascus Powder in a Hamster Model of Hyperlipidemia," Applied Microbiology and Biotechnology, Vol. 70, No. 5,
2006, pp. 533-540. doi:10.1007/s00253-005-0137-0

[6] Y. Aniya, T. Yokomakura, M. Yonamine, K. Shimada, T. Nagamine, M. Shimabukuro and H. Gibo, "Screening of Antioxidant Action of Various Molds and Protection of Monascus Anka against Experimentally Induced Liver Injuries of rats," General Pharmacology, Vol. 32, No. 2, 1999, pp. 225-231. doi:10.1016/S0306-3623(98)00183-9

[7] M. A. Dhale, S. Divakar, S. Umesh-Kumar and G. Vijayalakshmi, "Isolation and Characterization of Dihydromonacolin-MV from Monascus Purpureus for Antioxidant Properties," Applied Microbiology and Biotechnology, Vol. 73, No. 5, 2007, pp. 1197-1202. doi:10.1007/s00253-006-0578-0

[8] M. A. Dhale, S. Divakar, S. Umesh-Kumar and G. Vijayalakshmi, "Characterization of Dehydromonacolin-MV2 from Monascus Purpureus Mutant," Journal of Applied Microbiology, Vol. 130, No. 3, 2007, pp. 2168-2173. doi:10.1111/j.1365-2672.2007.03457.x

[9] H. P. Mohan-Kumari, K. A. Naidu, S. Vishwanatha, K. Narasimhamurthy and G. Vijayalakshmi, "Safety Evaluation of Monascus Purpureus Red Mould Rice in Albino Rats," Food and Chemical Toxicology, Vol. 47, No. 8, 2009, pp. 1739-1746. doi:10.1016/j.fct.2009.04.038

[10] L. Martinkova, P. Juzlova, V. Kren, Z. Kucerouva, V. Havlicek, P. Olsovsky, O. Hovorka, B. Rihova, D. Vesly, D. Vesela, J. Ulrichova and V. Prikrylova, "Biological ActiVities of Oligoketide Pigments of Monascus Purpureus," Food Additive and Contaminants, Vol. 16, No. 1, 1999, pp. 15-24. doi:10.1080/026520399284280

[11] C. Kim, H. Jung, Y. O. Kim and C. S. Shin, "Antimicrobial Activities of Amino Acid Derivatives of Monascus Pigments," FEMS Microbiology Letters, Vol. 264, No. 1, 2006, pp. 117-124. doi:10.1111/j.1574-6968.2006.00451.x

[12] H. Jung, C. Kim and C. S. Shin, "Enhanced Photostability of Monascus Pigments Derived with Various Amino Acids via Fermentation," Journal of Agriculture and Food Chemistry, Vol. 53, No. 18, 2005, pp. 7108-7114. doi:10.1021/jf0510283

[13] J. C. De Man, M. Rogosa and M. E. Sharpe, "A Medium for the Cultivation of Lactobacilli," Journal of Applied Bacteriology, Vol. 23, No. 1, 1960, pp. 130-135. doi:10.1111/j.1365-2672.1960.tb00188.x

[14] P. K. Mukherjee, R. Balasubramanian, K. Saha, B. P. Saha and M. Pal, "Antibacterial Efficiency of Nelumbo nucifera (Nymphaeaceae) Rhizomes Extract," Indian Drugs, Vol. 32, No. 6, 1995, pp. 274-276.

[15] R. Y. Y. Chiou and S. L. Cheng, "Isoflavone Transformation during Soybean Koji Preparation and Subsequent Miso Fermentation Supplemented with Ethanol and $\mathrm{NaCl}$," Journal of Agriculture and Food Chemistry, Vol. 49, No. 8, 2001, pp. 3656-3660. doi:10.1021/jf0015241

[16] M. Blois, "Antioxidant Determinations by the Use of a Stable Free Radical," Nature, Vol. 181, 1958, pp. 11991200. doi:10.1038/1811199a0

[17] J. H. Moon and J. Terao, "Antioxidant Effect of Caffeeic 
Acid and Dihydrocaffeeic Acid in Lard and Human Low-Density Lipoprotein," Journal of Agriculture and Food Chemistry, Vol. 46, No. 12, 1998, pp. 5062-5065. doi:10.1021/jf9805799

[18] G. B. Kovachich and O. P. Mishra, "Stabilization of AsCorbic Acid and Norepinephrine in Vitro by the Subcellular Fractions of Rat Cerebral Cortex," Neuroscience Letters, Vol. 52, No. 1-2, 1984, pp. 153-158. doi:10.1016/0304-3940(84)90366-5

[19] M. Oyaizu, "Studies on Product of Browning Reaction Prepared from Glucose Amine," Japanese Journal of Nutrition, Vol. 44, No. 6, 1986, pp. 307-315. doi:10.5264/eiyogakuzashi.44.307

[20] F. Guarner and J. R. Malagelada, "Gut Flora in Health and Disease," Lancet, Vol. 361, No. 9356, 2003, pp. 512519. doi:10.1016/S0140-6736(03)12489-0

[21] H. C. Wong and Y. S. Bau, "Pigmentation and Antibacterial Activity of Fast-Neutron and X-Ray Induced Strains of M. purpureus Went," Plant Physiology, Vol. 60, No. 4, 1977, pp. 578-581. doi: $10.1104 /$ pp.60.4.578

[22] D. O. Otieno, J. F. Ashton and N. P. Shah, "Stability of
$\beta$-Glucosidase Activity Processing by Bifidobacterium and Lactobacillus spp in Fermented Soymilk during Processing and Storage," Journal of Food Science, Vol. 70, No. 4, 2005, pp. 236-241. doi:10.1111/j.1365-2621.2005.tb07194.x

[23] W. H. Hsu, B. H. Lee and T. M. Pan, "Red Mold Dioscorea-Induced G2/M Arrest and Apoptosis in Human Oral Cancer Cells," Journal Science and Food Agriculture, Vol. 90, No. 15, 2010, pp. 2709-2715. doi:10.1002/jsfa.4144

[24] K. Setchell, N. Brown, N. L. Zimmer, W. Brashear, B. Wolfe, A. Kirschour and J. Heubi, "Evidence for Lack of Absorption of Soy Isoflavone Glycosides in Humans, Supporting the Crucial Role of Intestinal Metabolism for Bioavailability," American Journal of Clinical Nutrition, Vol. 76, No. 2, 2002, pp. 447-453.

[25] Y. Kawakami, W. Tsurugasaki, S. Nakamura and K. Osada, "Comparison of Regulative Functions between Dietary Soy Isoflavones Aglycone and Glucoside on Lipid Metabolism in Rats Fed Cholesterol," Journal of Nutritional Biochemistry, Vol. 16, No. 4, 2005, pp. 205-212. doi:10.1016/j.jnutbio.2004.11.005 